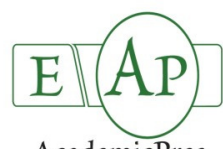

AcademicPres

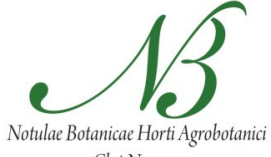

Cluj-Napoca

\title{
Responses of '0900 Ziraat' Sweet Cherry Variety Grafted on Different Rootstocks to Salt Stress
}

\author{
Cenk KÜÇÜKYUMUK ${ }^{1 *}$, Halit YILDIZ1 ${ }^{1}$ Zeliha KÜÇÜKYUMUK² \\ Ali ÜNLÜKARA ${ }^{3}$
}

\author{
IFruit Research Station, 32500,Eğirdir, Isparta, Turkey; cenkkucukyumuk@hotmail.com ("correspondingauthor); halityildiz@hotmail.com \\ ${ }^{2}$ Department of Soil Science and Plant Nutrition, Agricultural Faculty, Suleyman Demirel University, 32260, Isparta, Turkey; zelihakucukyumuk@sdu.edu.tr \\ ${ }^{3}$ Department of Biosystem Enginerring, Agricultural Faculty, Erciyes University, Kayseri, Turkey; unlukara@gmail.com
}

\begin{abstract}
This study was conducted to determine the responses of '0900 Ziraat' sweet cherry cultivar grafted on mazzard (Prunus avium L.) and mahaleb (P. mahaleb L.) rootstocks, to different irrigation water salinity levels. One year old sweet cherry trees were planted in 50-liter pots at Eğirdir Fruit Research Station (Isparta, Turkey). Four different irrigation water salinity levels $\left(S_{1}=0.3 \mathrm{dS} \mathrm{m}^{-1}, S_{2}=2.0 \mathrm{dS} \mathrm{m}{ }^{-1}, S_{3}=4.0 \mathrm{dS} \mathrm{m}^{-1}\right.$ and $\left.S_{4}=6 \mathrm{dS} \mathrm{m}^{-1}\right)$ were used for both variety/rootstock combinations. The results showed that sweet cherry trees grafted on mahaleb rootstocks extracted more water under saline conditions than the ones grafted on mazzard. Water salinity levels caused more damage on 0900/mazzard than on 0900/mahaleb. Towards the end of the growing period, plant deaths were detected in $S_{3}$ and $S_{4}$ treatments. While midday leaf water potential (LWP) ranged from -1.54 to $-3.33 \mathrm{MPa}$, stomatal conductance ranged from 26.8 to $199.5 \mathrm{mmol} \mathrm{m} \mathrm{m}^{-1}$. It was determined that both parameters decreased towards the end of the growing period for all treatments. Sodium ( $\mathrm{Na}$ ) uptake was excluded by 0900/mahaleb rootstocks, but chloride $\left(\mathrm{Cl}^{-}\right)$uptake was excluded only for higher saline conditions. As a result, mahaleb (P. mahaleb L.) rootstock could be recommended to be used as rootstock for sweet cherry culture under saline conditions.
\end{abstract}

Keywords: chlorophyll content, Prunus avium L., P. mahaleb L., salinity, stomatal conductance

\section{Introduction}

Salinity is the most common problem in irrigated lands not only of Turkey and but also of the world. Salinity is one of the most important problems threatening both arid and semi-arid agricultural lands. Throughout the world, seventeen percent of the agricultural lands are irrigated and approximately $20 \%$ are under direct threat of salinity (Pitman and Läuchli, 2002; Tuteja, 2007). Increased salinity levels deteriorate soil texture and significantly limit crop quality and yields. In addition, salinity-induced stress influence plant growth through various physiological, biochemical and molecular changes exerted in plant internal mechanisms (Ashraf and Foolad, 2007). Impacts of salinity on plant and soil mechanisms should clearly be identified in order to grow a crop with saline water or saline soil (Düzdemir et al., 2009).

Turkey, with an annual production of 403.128 tons, is the greatest sweet cherry producer of the world (FAO, 2013). '0900 Ziraat' is the most common variety of Turkey and it is known as "Turkish cherry" in Europe (Demirtaş and Sarısu, 2011). Besides, $90 \%$ of sweet cherry growers prefer ' 0900 Ziraat' for new orchards (Öztürk et al., 2005). The variety is commonly grafted on mazzard (Prunus avium L.) and mahaleb (Prunus mahaleb L.) rootstocks (Eroğul, 2012). Cherries are classified as sensitive to salinity (KotubyAmecher et al., 2000). Rootstocks can influence scion tolerance to salinity (Perry, 1987). Therefore, the effects of saline irrigation water on sweet cherry varieties grafted on different rootstocks should be determined. Therefore, the present study was conducted to investigate the response of '0900 Ziraat' variety grafted on mazzard (Prunus avium L.) and mahaleb (Prunus mahaleb L.) rootstocks to different salinity levels of irrigation water.

\section{Materials and methods}

\section{Study are and plant material}

This study was conducted at Fruit Research Station, Eğirdir, Isparta, Turkey in 2013. One year old '0900 Ziraat' sweet cherry variety grafted on mazzard (Prunus avium L.) and mahaleb (Prunus mahaleb L.) rootstocks were used in the study. Soil mixture placed into 50 liter-pots (bottom diameter: $35 \mathrm{~cm}$, upper diameter: $43 \mathrm{~cm}$, height: $42 \mathrm{~cm}$ ) was consisted of sand:loamy soil:peat:farm yard manure (1:2:1:0.5 ratios) and the main characteristics of the mixture are provided in Table 1 . 
Table 1. Properties of soil mixture in pots

\begin{tabular}{lc}
\hline Texture & Clay loam \\
\hline Saturation $(\%)$ & 68.2 \\
Salinity $\left(\mathrm{dS} \mathrm{m}^{-1}\right)$ & 0.630 \\
$\mathrm{pH}$ & 7.18 \\
Lime $(\%)$ & 11.14 \\
Organic matter $(\%)$ & 6.3 \\
$\mathrm{P}(\mathrm{ppm})$ & 170 \\
$\mathrm{~K}(\mathrm{ppm})$ & 294 \\
$\mathrm{Ca}(\mathrm{ppm})$ & 1102 \\
$\mathrm{Mg}(\mathrm{ppm})$ & 1701 \\
\hline
\end{tabular}

\section{Salinity treatments}

To determine the responses of these two different variety/rootstock combinations, four different saline irrigation water treatments $\left(S_{1}=0.3 \mathrm{dS} \mathrm{m}^{-1}, S_{2}=2.0 \mathrm{dS} \mathrm{m}^{-1}\right.$, $S_{3}=4.0 \mathrm{dS} \mathrm{m}^{-1}$ and $S_{4}=6.0 \mathrm{dS} \mathrm{m}^{-1}$ ) were used. To obtain these saline waters, $\mathrm{CaCl}_{2}, \mathrm{MgSO}_{4}$ and $\mathrm{NaCl}$ salts were added to the well water of the Research Station. The saline waters had $1 / 1 \mathrm{meq} \mathrm{I}^{-1} \mathrm{Ca} / \mathrm{Mg}$ ratio and Sodium Adsorption Ratios (SAR) were around 5 . The water of the well $\left(E C=0.3 \mathrm{dS} \mathrm{m}^{-1}\right.$ and SAR=1.04) was used as control treatment $\left(\mathrm{S}_{1}\right)$. Saline water treatments were initiated at the end of full bloom of sweet cherry trees (May). Irrigation interval was considered as 5 days for all treatments. Trees were removed after defoliation on November 2013.

\section{Calculation of irrigation water and plant water consumption}

Field capacities of the pots were determined in accordance with Ünlükara et al. (2010). At the beginning of the experiment, the mixture in the pot without plant was saturated with water and then the pots were covered with aluminium foil to prevent evaporation. The pot weight without any leaching water from the bottom of the pot's drainage outlets was considered as field capacity $\left(W_{F C}\right)$. Depleted water from the field capacity or the amount of net irrigation water was determined by weighing the pots just before each irrigation event. To prevent excessive salt accumulation in the plant root zone and to obtain nearly constant soil salinity for each treatment, leaching water was added to net irrigation water by using Equation (1).

$$
I=\frac{\frac{w_{F C^{-}}-W}{\rho}}{1-L F}
$$

Where $L F$ is the leaching fraction (volume of water drained/volume of water applied), $W_{F C}$ and $\mathrm{W}$ are the field capacity weight $(\mathrm{kg})$ and pot weight just before irrigation $(\mathrm{kg})$, respectively and $\rho$ is water density $\left(1 \mathrm{~kg} \mathrm{~L}^{-1}\right)$.

Drained water volume from the pots to the pot pads were measured when the leaking ceased out. Electrical conductivity (EC) of the drainage water at two irrigations intervals was also determined from the beginning to the end of the experiment by using an EC meter (İnolab-Cond 7110 model).

By using soil water balance Equation (2), plant water consumption was determined:

$$
E T=I-D \pm \Delta S
$$

Where, I is the amount of irrigation water $(\mathrm{L}), \mathrm{D}$ is the amount of drainage water $(\mathrm{L})$ and $\Delta S$ is the difference in soil water contents between the beginning and the end of experiment $(\mathrm{L})$.

\section{Midday leaf water potential and stomatal conductance}

Leaf water potential (LPW) was measured by a pressure chamber on the field (PMS Instrument Company, Model 1000) every 10 days in July and August, to determine the effects of different salinity levels on LWP. LWP measurements were carried out according to the method of midday leaf water potential on one plant for each treatment. Leaf samples were collected from the sun-exposed mature leaves of one year old shoots from different sides of the selected plants in every treatment. At least 2 leaves per plant were sampled between 12:00-14:00 of the day, before irrigations.

Stomatal conductance (SC) measurements were also carried out simultaneously with leaf water potential measurements, on the same plants by a porometer (Delta-T, Porometer-AP4). Leaf samples were taken from the sunexposed mature leaves of one year old shoots from different sides of the selected plants in every treatment. At least 3 leaves per tree were sampled and two repetitive readings were taken from each leaf.

\section{Leaf scorch, plant and root weight}

Leaf scorch based on 0-3 scale for two different rootstocks before the last irrigation was determined to evaluate the effects of different salinity levels (Martinez-Barraso and Alvarez, 1997). According to 0-3 scale, it was noted as 0: no damage, 1: slight drying on leaf tips or on leaf edges, 2: drying of $50 \%$ of leaf area and 3: drying more than $50 \%$ of leaf area or drying of the whole leaf area and plant death. At the end of the season, plants were removed from the pots by leaching. Then plant weight and root weight under scion area were determined by using a precise balance $( \pm 1.0 \mathrm{~g})$.

\section{$\mathrm{Na}$ and $\mathrm{Cl}^{-}$analysis}

To identify toxic ion concentrations in leaves of 0900/mazzard and 0900/mahaleb combinations under different salinity conditions, $\mathrm{Na}$ and $\mathrm{Cl}^{-}$contents were determined. Grounded $0.25 \mathrm{~g}$ leaf sample was wet digested at $180^{\circ} \mathrm{C}$ in a microwave oven (Cem MARSXpress) for 15 min. Then, the samples were dissolved in $10 \mathrm{ml} \mathrm{HNO}_{3}$ and filled up to $50 \mathrm{ml}$ with distilled water and sodium was determined by atomic absorption spectrophotometer (Varian AA240FS). Chloride concentration in ground samples was determined by titration with silver nitrate. At the end of the experiment, soil salinities of the soil samples taken along the root depth for each pot were determined according to soil saturation paste extract method (Richards, 1954). Extracted soil water EC was measured by an EC meter (İnolab-Cond 
216

7110 model). Chlorophyll $a$ and chlorophyll $b$ analyses were carried out according to Withan et al. (1971).

\section{Experimental design and statistical analysis}

Experiments were carried out in randomized plots experimental design with three replications. Each replication had three plants. Resultant data were subjected to analysis of variance (ANOVA) with JUMP software and LSD test was used to compare the differences among the treatments.

\section{Results and discussions}

\section{Soil salinity and drainage water salinity}

Soil salinity of $S_{1}, S_{2}, S_{3}$ and $S_{4}$ treatments were 6.5, 3.2, 2.5 and 2.2 times higher than their irrigation water salinity for 0900/mazzard and 5.4, 4.5, 3.5 and 2.8 times higher for 0900/mahaleb (Table 2). It should be noticed that mean soil salinity of $0900 /$ mahaleb combination $(10.24 \mathrm{dS} / \mathrm{m})$ was higher than soil salinity of $0900 /$ mazzard $(7.93 \mathrm{dS} / \mathrm{m})$. The reason for higher soil salinity values of $0900 /$ mahaleb treatments is that the trees with mahaleb rootstocks extracted more water under saline conditions than the trees with mazzard rootstocks. There were four and three statistical groups respectively for 0900/mazzard and 0900/mahaleb trees. $S_{3}$ and $S_{4}$ treatments of 0900/mahaleb trees were placed in the same group. Soil salinity of 0900/mahaleb trees did not increase after $4 \mathrm{dS} \mathrm{m}^{-1}$ salinity level. But soil salinity of 0900/mazzard trees increased even after $6 \mathrm{dS}$ $\mathrm{m}^{-1}$ salinity level. Ayers and Westcot (1989) stated that plants extract nearly pure water from soil water and leave salts into soil. This causes salt accumulation in irrigated soils unless leaching. More water extraction means more salt accumulation in soil. Therefore, soil salt accumulation ratios decreased with increasing irrigation water salinity levels.

In adequately drained sites, leaching is a key factor to prevent excess salt accumulation in root zone (Ayers and Westcot, 1989). Leaching fraction of the experiment was about 0.17 (Table 2). Leaching water removes salt below root zone. Drainage water salinities of the treatments throughout the growing season are presented in Fig. 1. Higher saline water applications produced higher drainage water salinity. Similar results were also reported by Yurtseven et al. (2005) for tomato and Semiz et al. (2012) for fennel.

Table 2. Effects of irrigation water salinity on soil salinity and plant water consumption of 0900/mazzard and 0900/mahaleb trees

\begin{tabular}{|c|c|c|c|c|}
\hline Parameters & \multicolumn{4}{|c|}{ '0900 Ziraat' sweet cherry variety } \\
\hline \multirow[b]{4}{*}{$\begin{array}{l}\text { Plant water } \\
\text { consumption (liter) }\end{array}$} & \multicolumn{4}{|c|}{ Irrigation water salinity $\left(\mathrm{dS} \mathrm{m}^{-1}\right)$} \\
\hline & $\begin{array}{l}0.3 \\
\left(S_{1}\right)\end{array}$ & $\begin{array}{l}2.0 \\
\left(S_{2}\right)\end{array}$ & $\begin{array}{l}4.0 \\
\left(S_{3}\right)\end{array}$ & $\begin{array}{l}6.0 \\
\left(S_{4}\right)\end{array}$ \\
\hline & \multicolumn{4}{|c|}{0900 cherry variety / mazzard rootstock } \\
\hline & 64.90 & 50.45 & 40.20 & 31.20 \\
\hline Leaching fraction & 0.16 & 0.17 & 0.17 & 0.17 \\
\hline \multirow[t]{3}{*}{ Soil salinity $\left(\mathrm{d} S \mathrm{~m}^{-1}\right)$} & $1.94 \mathrm{~d}^{* *}$ & $6.37 c$ & $9.96 \mathrm{~b}$ & $13.44 \mathrm{a}$ \\
\hline & \multicolumn{4}{|c|}{0900 cherry variety / mahaleb rootstock } \\
\hline & $\begin{array}{l}0.3 \\
\left(S_{1}\right)\end{array}$ & $\begin{array}{l}2.0 \\
\left(S_{2}\right)\end{array}$ & $\begin{array}{l}4.0 \\
\left(S_{3}\right)\end{array}$ & $\begin{array}{l}6.0 \\
\left(S_{4}\right)\end{array}$ \\
\hline $\begin{array}{l}\text { Plant water } \\
\text { consumption (liter) }\end{array}$ & 84.7 & 62.5 & 46.4 & 40.7 \\
\hline Leaching fraction & 0.16 & 0.17 & 0.17 & 0.17 \\
\hline Soil salinity $\left(\mathrm{d} S \mathrm{~m}^{-1}\right)$ & $1.61 c^{* *}$ & $8.89 \mathrm{~b}$ & $13.94 \mathrm{a}$ & $16.58 \mathrm{a}$ \\
\hline
\end{tabular}

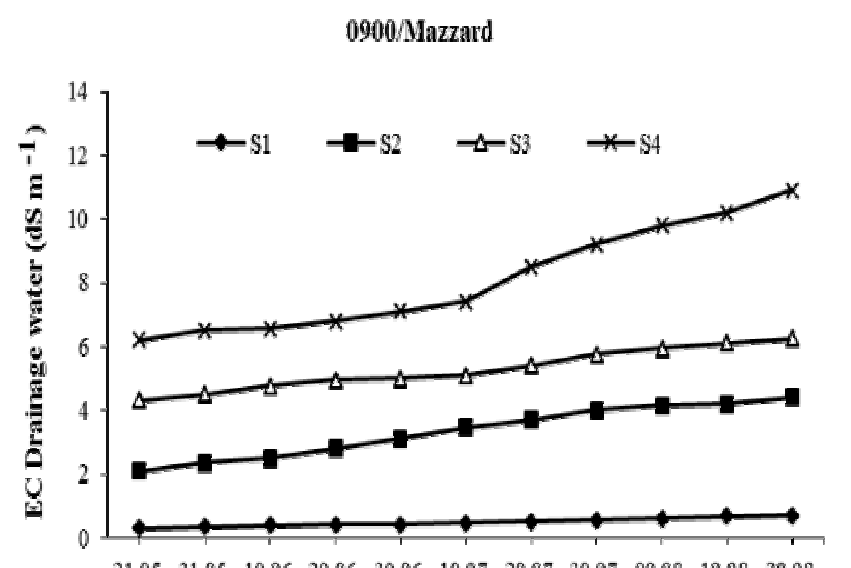

21,05, 31,05, 10,06, 20,06, 30,06, 10,07, 20,07,30,07, 09,08, 19.08, 29,08 ,

0900/Mahaleb

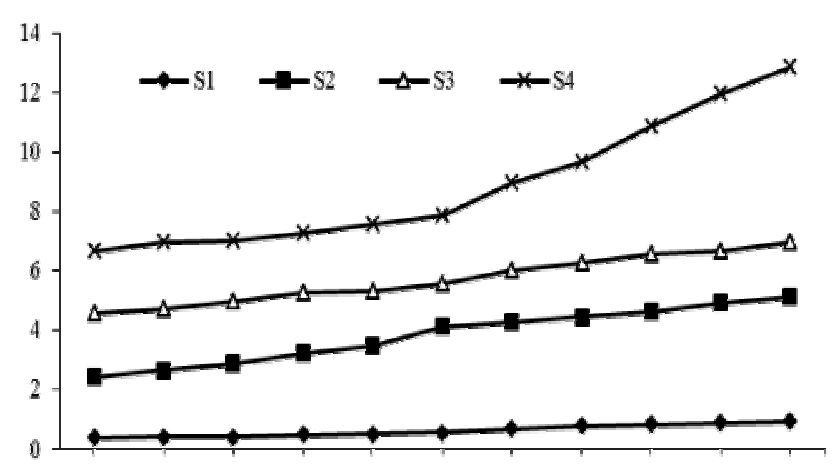

21.05, 31.05, 10,06, 20,06, 30,06, 10,07, 20.07, 30.07, 09,08, 19,08, 29,08.

Fig. 1. Change in drainage water salinities

\section{Plant water consumption}

Water consumption in $S_{1}\left(0.3 \mathrm{dS} \mathrm{m}^{-1}\right)$ treatments was more than $S_{4}$ treatments for both rootstocks (Fig. 2). 0900/mahaleb sweet cherry trees exhibited better growth than 0900/mazzard sweet cherry trees in all treatments and consumed more water. Compared to $S_{1}$ treatment, decreases in water consumptions of $S_{2}, S_{3}$ and $S_{4}$ treatments were respectively $22.3 \%, 38.1 \%$ and $51.9 \%$ for $0900 /$ mazzard sweet cherry trees and were respectively $26.2 \%, 45.2 \%$ and $51.9 \%$ for $0900 /$ mahaleb sweet cherry trees (Table 2). Water salinity had similar effects on water consumption of both variety/rootstock combinations. Yang $e t$ al. (2002) reported that excessive amounts of soluble salts in the soil reduced plant water use. Smets et al. (1997) reported that irrigation water quality affected plants transpiration so that transpiration decreased between $8 \%$ and $32 \%$ when EC of irrigation water increased from $1 \mathrm{dS} \mathrm{m}^{-1}$ to $4 \mathrm{dS} \mathrm{m}^{-1}$. High salt content of irrigation water increases osmotic potential around root zone. Due to high osmotic potential, roots cannot use water efficiently (Parker and Suarez, 1990). Some researchers determined that plant water consumption was affected from water salinity and water consumption decreased with increasing water salinity (Germana et al., 2000; Murkute et al., 2005). Current findings also revealed an effect of decreasing water consumptions with the increasing salinity stress levels.

\section{Fresh plant and root weights}

Increasing water salinity affected plant growth negatively and the least fresh plant weights were obtained from $S_{4}$ treatments of 
0900/Mazzard

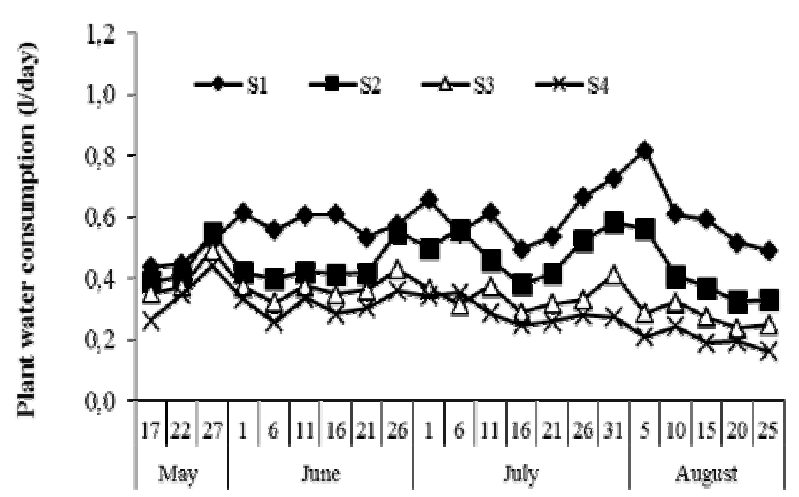

0900/Mahaleb

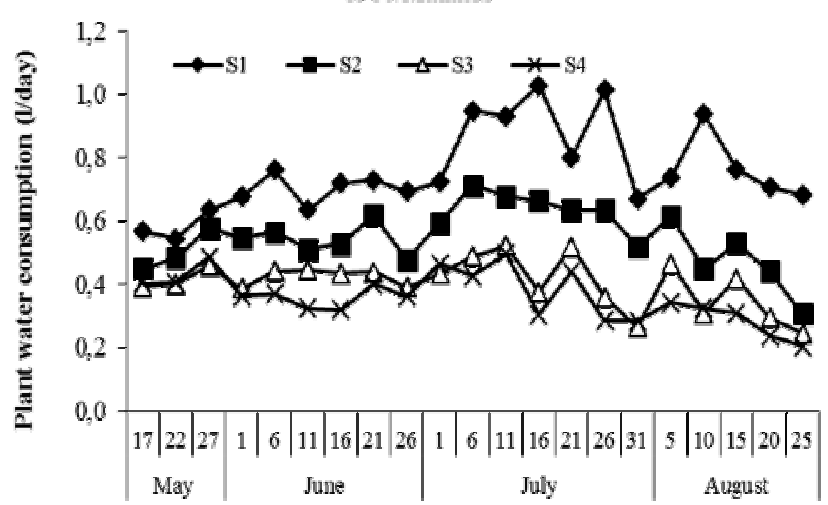

Fig. 2. Daily plant water consumption of cherry trees

Table 3. Effects of salinity on fresh plant and root weights of 0900/mazzard and 0900/mahaleb trees

\begin{tabular}{|c|c|c|c|c|}
\hline \multirow{2}{*}{$\begin{array}{l}\text { Variety/rootstock } \\
\text { combination }\end{array}$} & \multicolumn{4}{|c|}{ Irrigation water salinity $\left(\mathrm{d} S \mathrm{~m}^{-1}\right)$} \\
\hline & $\begin{array}{l}0.3 \\
\left(S_{1}\right)\end{array}$ & $\begin{array}{l}2.0 \\
\left(S_{2}\right)\end{array}$ & $\begin{array}{l}4.0 \\
\left(S_{3}\right)\end{array}$ & $\begin{array}{l}6.0 \\
\left(S_{4}\right)\end{array}$ \\
\hline & \multicolumn{4}{|c|}{ Fresh plant weights (g) (planting) } \\
\hline 0900/mazzard & $326.3 n s$ & 331.3 & 321.9 & 313.1 \\
\hline \multirow[t]{2}{*}{ 0900/mahaleb } & $405.7 n s$ & 412.9 & 406.3 & 380.6 \\
\hline & \multicolumn{4}{|c|}{ Fresh plant weights (g) (removing) } \\
\hline 0900/mazzard & $584.0 \mathrm{~B}^{* *} \mathrm{a}^{* *}$ & $485.0 \mathrm{~B}^{* *} \mathrm{~b}$ & $417.9 \mathrm{~B}^{* *} \mathrm{c}$ & $384.2 \mathrm{~B}^{* *} \mathrm{~d}$ \\
\hline \multirow[t]{2}{*}{ 0900/mahaleb } & $742.1 \mathrm{Aa}^{* *}$ & $651.4 \mathrm{Ab}$ & $566.3 \mathrm{Ac}$ & $485.6 \mathrm{Ad}$ \\
\hline & \multicolumn{4}{|c|}{ Fresh plant weight increase (\%) } \\
\hline 0900/mazzard & 79.0 & 46.4 & 29.8 & 22.7 \\
\hline \multirow[t]{2}{*}{ 0900/mahaleb } & 82.9 & 57.8 & 39.4 & 27.6 \\
\hline & \multicolumn{4}{|c|}{ Fresh root weights $(\mathrm{g})$} \\
\hline 0900/mazzard & $346.7 \mathrm{~A}^{n s} \mathrm{a}^{* *}$ & $230.0 \mathrm{~A}^{n s} \mathrm{~b}$ & $153.3 \mathrm{~A}^{n s} \mathrm{c}$ & $101.7 \mathrm{~A}^{n s} \mathrm{~d}$ \\
\hline \multirow[t]{2}{*}{ 0900/mahaleb } & $405.0 \mathrm{Aa}^{* *}$ & $265.0 \mathrm{Ab}$ & $178.3 \mathrm{Ac}$ & 126.7 Ad \\
\hline & \multicolumn{4}{|c|}{ Fresh root weight reduction (\%) } \\
\hline 0900/mazzard & 0 & 33.7 & 55.8 & 70.7 \\
\hline 0900/mahaleb & 0 & 34.6 & 56.0 & 68.7 \\
\hline
\end{tabular}

Means followed by the same letter are not significantly different, ${ }^{* *} \mathrm{p}<0.01$, ns: no significant

both variety/rootstock combinations (Table 3). According to rootstock effects, there were two statistical groups and 0900/mahaleb trees were at first group. There were four groups for both 0900/mazzard and 0900/mahaleb trees according to salinity effect. Fresh plant weight increasing ratio (\%) in 0900/mahaleb trees was more than in 0900/mazzard trees. Trees in $S_{4}$ treatments had the least root development (Table 3). According to the results of fresh root weights, there were no significant differences between rootstocks. Fresh root weight reduction was similar for both rootstocks. Therefore, it can be said that salt stress influenced root development of both rootstocks similarly. There were four statistical groups for each rootstock according to salt stress effects. That means of each irrigation water salinity treatment affected root development clearly.

Perry (1987) reported that cherry (Prunus cerasus) rootstocks could greatly affect the scion's tolerance to salinity. Plant growth is limited by salinity (Blumwald et al., 2000). Sotiropoulos et al. (2006) reported that increasing water salinity affected negatively plant growth of CAB $6 \mathrm{P}$ and Gisela 5 rootstocks. In the present study, increasing salt stress suppressed plant development. Arıci and Eraslan (2012) reported that increasing $\mathrm{NaCl}$ concentration suppressed plant development of Colt sweet cherry rootstock. Similar results were also reported by Ertürk et al. (2007) and Reddy and Iyengar (1999). It was stated that soil and water salinity affected negatively plant growth
(Tanji, 1990). Lutfor Rahman et al. (1999) and Karakas et al. (2000) reported that root weights were affected negatively from increasing irrigation water salinity. Reduced vegetative development with increasing salinity levels were also observed in this study.

Negative linear inverse relations were determined between soil salinity and the other parameters. While soil salinity increased, plant water consumption decreased. Plant and root weights were also affected by increasing soil salinity. $\mathrm{R}^{2}$ values for ET were 0.88 and 0.60 , for fresh plant weight were 0.77 and 0.64 , for fresh root weight were 0.80 and 0.77 for $0900 /$ mazzard and $0900 /$ mahaleb trees, respectively. It can be said that 0900/mazzard sweet cherry trees were more sensitive to increasing salinity than $0900 /$ mahaleb trees.

\section{Leafscorch}

Leaf scorch increased with irrigation water salinity (Fig. 3). Plants deaths were observed in $S_{3}$ and $S_{4}$ treatments towards the end of the growing period of both variety/rootstock combinations. It was determined that leaves of sweet cherry trees grafted onto mazzard rootstock suffered more than sweet cherry trees grafted onto mahaleb rootstock because of increasing irrigation water salinity. $\mathrm{Na}$ and $\mathrm{Cl}^{-}$ions could accumulate in leaves at high concentrations and cause leaf scorch (Shannon and Grieve, 1999). One of detrimental effects of salt stress is leaf damage (Blumwald et al., 2000). The first reaction to salt for 

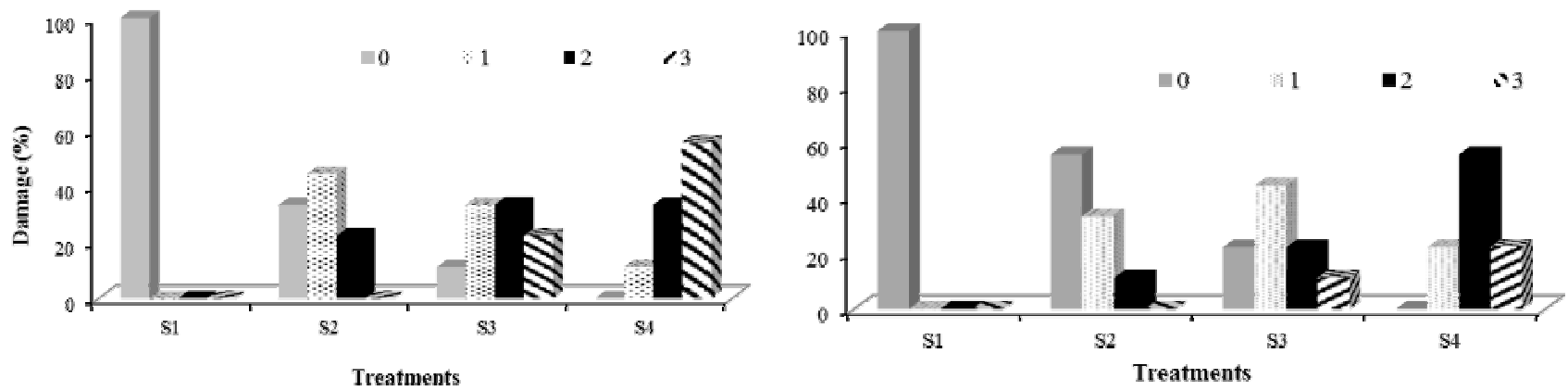

Fig. 3. Degree of salt damage on leaves of 0900/mazzard and 0900/mahaleb trees
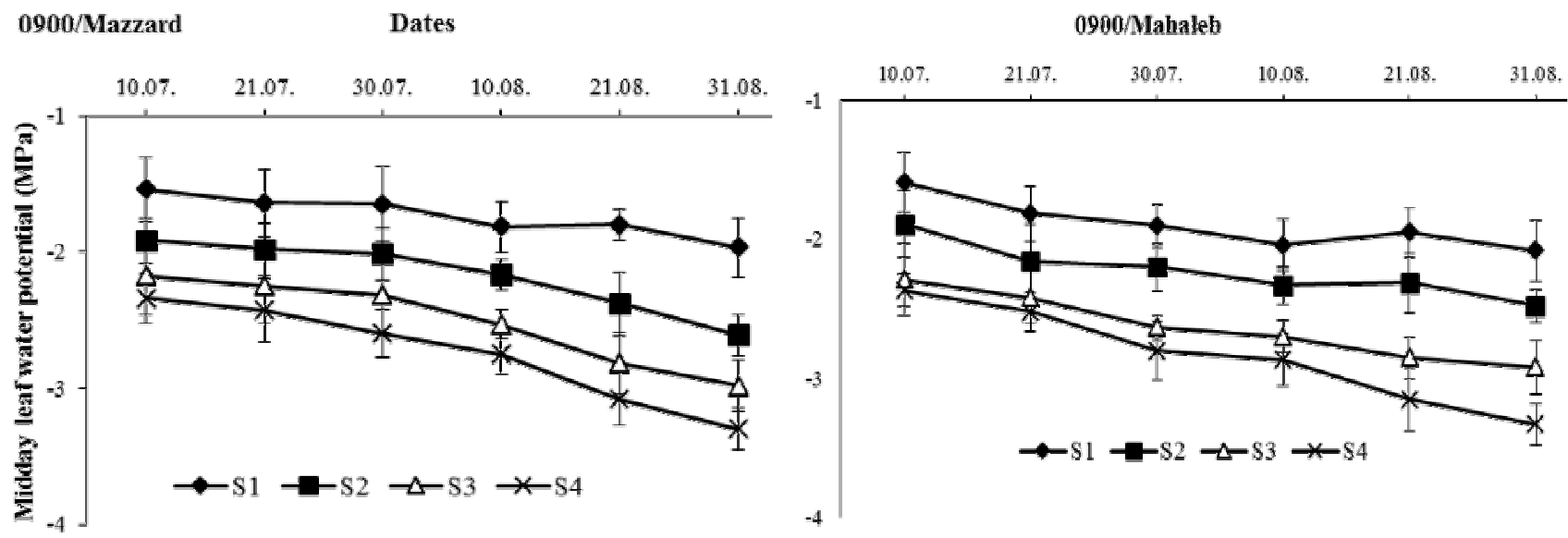

Fig. 4. Midday leaf water potential of the treatments; Error bars indicate standard errors of the means
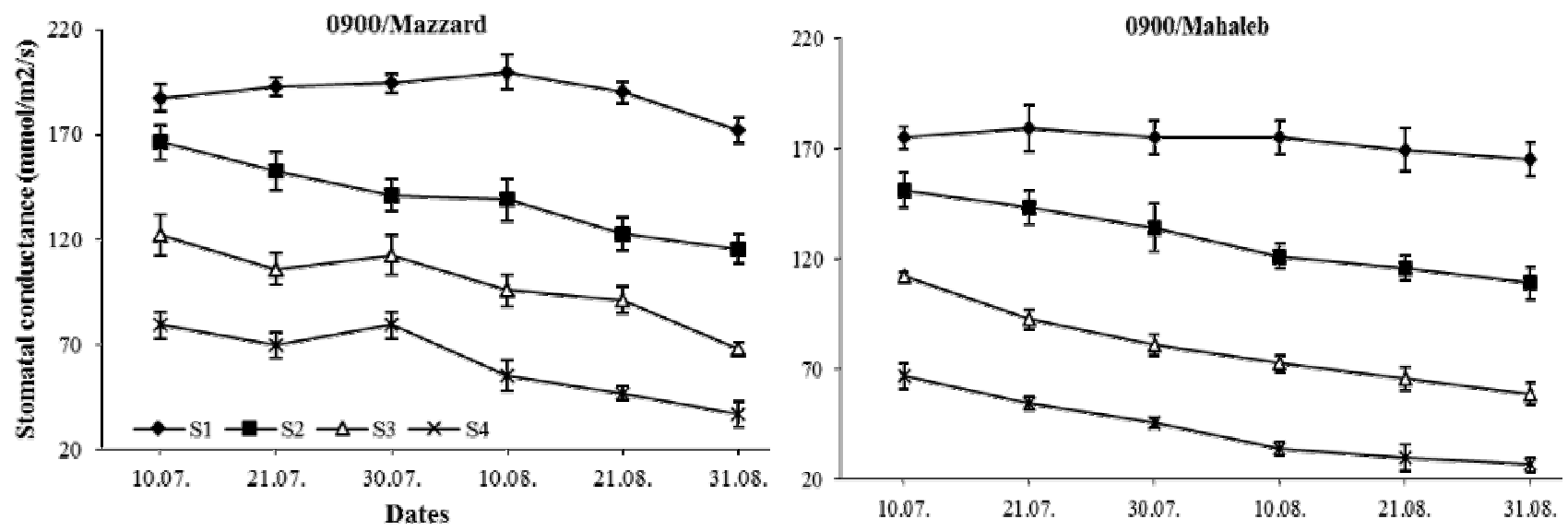

Fig. 5. Stomatal conductance of the treatments; Error bars indicate standard errors of the means

glycophyte plants can be seen on leaves. The density of leaf scorch observed under conditions that hinder growth and development in salinity stress conditions can be used as a parameter for the salt tolerance of plants. Defoliation is frequently observed under increasing salinity stress conditions (Hasegawa et al., 1986; Okubo and Sakuratani, 2000). The first necrosis related with increasing salinity stress was observed in mature leaves in this study. Karakas et al. (2000) and Lauchli and Epstein (1990) stated that leaf scorch increased once with the irrigation water salinity. Lauchli and Epstein (1990) also reported increasing plant deaths with increasing salinity levels. Sweet cherry trees used in this study had similar responses. Sotiropoulos et al.
(2006) reported that most leaves on CAB 6 rootstocks retained on trees until the end of their experiment, but Gisela 5 plants showed higher defoliation rates than $\mathrm{CAB} 6$ rootstocks because of salt stress.

\section{Leaf waterpotential}

LWP values decreased towards the end of the growing season with salt accumulation in the soil (Fig. 4). The least midday LWP values were observed in $S_{4}$ treatments of both variety/rootstock combinations. It was determined that $S_{3}$ and $S_{4}$ treatments had more negative effects on midday LWP than $S_{2}$ treatment. LWP values were affected negatively because plant 
Table 4. Effects of salinity on $\mathrm{Na}$ and $\mathrm{Cl}^{-}$concentration of $0900 /$ mazzard and 0900/mahaleb trees

\begin{tabular}{ccccc}
\hline \multirow{2}{*}{$\begin{array}{c}\text { Variety/rootstock } \\
\text { combination }\end{array}$} & 0.3 & \multicolumn{4}{c}{ Irrigation water salinity $\left(\mathrm{dS} \mathrm{m}{ }^{-1}\right)$} \\
\cline { 2 - 5 } & $\left(\mathrm{S}_{1}\right)$ & $\left(\mathrm{S}_{2}\right)$ & $\left(\mathrm{S}_{3}\right)$ & 6.0 \\
& \multicolumn{4}{c}{$\mathrm{Na}(\mathrm{ppm})$ (for leaves $)$} \\
\cline { 2 - 5 } $0900 /$ mazzard & $663 \mathrm{~A}_{4}^{* *} \mathrm{c}^{* *}$ & $806 \mathrm{~A}^{* *} \mathrm{~b}$ & $899 \mathrm{~A}^{* *} \mathrm{ab}$ & $968 \mathrm{~A}^{* *} \mathrm{a}$ \\
\hline $0900 /$ mahaleb & $312 \mathrm{Bb}^{*}$ & $435 \mathrm{Bab}$ & $485 \mathrm{Ba}$ & $522 \mathrm{Ba}$ \\
& \multicolumn{4}{c}{$\mathrm{Cl}^{-}(\%)$ (forleaves) } \\
\cline { 2 - 5 } $0900 /$ mazzard & $1.40 \mathrm{~A}^{n s} \mathrm{c}^{* *}$ & $3.68 \mathrm{~A}^{n *} \mathrm{~b}$ & $5.54 \mathrm{~A}^{*} \mathrm{a}$ & $5.97 \mathrm{~A}^{*} \mathrm{a}$ \\
$0900 /$ mahaleb & $1.18 \mathrm{~A} \mathrm{c}^{* *}$ & $3.52 \mathrm{~A} \mathrm{~b}$ & $3.66 \mathrm{~B} \mathrm{~b}$ & $5.0 \mathrm{~B} \mathrm{a}$ \\
\hline
\end{tabular}

Capital letters indicate the difference between both rootstock, small letter indicate the differences among the saline treatments

Means followed by the same letter are not significantly different, ${ }^{*} \mathrm{p}<0.05,{ }^{* *} \mathrm{p}<0.01$, ns: no significant

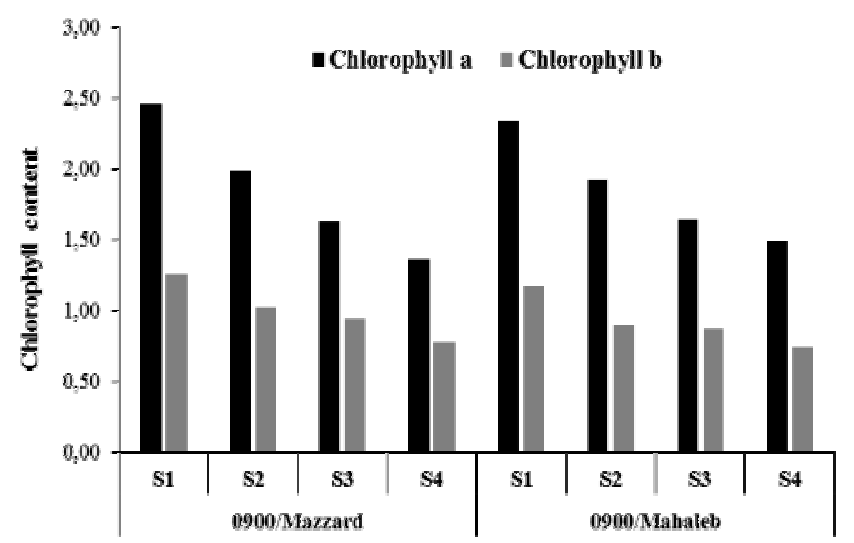

Fig. 6. Chlorophyll $a$ and chlorophyll $b$ contents of sweet cherry trees

water consumption decreased with increasing irrigation water salinity and also salt accumulation increased on leaves (Table 2). According to LWP values, $S_{2}$ treatments affected 0900/mazzard trees more than 0900/mahaleb trees. Some of researchers stated that leaf water potential decreased with increasing irrigation water salinity (Tattini et al., 1995; Murkute et al., 2005).

\section{Stomatal conductance}

It was determined that stomatal conductance further decreased from mid growing season (July) to the end of the growing period in all treatments except for $S_{1}$ treatments (Fig. 5). Results of $S_{3}$ and $S_{4}$ treatments were close to each other especially towards the end of the growing period, similar to LWP values. When plants are exposed to salinity stress, they close their stomata firstly, in order to prevent water loss. Stomatal closure gives rise to decreased stomatal conductance (Ashraf, 2004; Munns and Tester, 2008). Similar to the current findings, previous researchers reported that stomatal conductance decreased with increasing salinity stress (Downton et al., 1990).

\section{Na and $C t$ analyses}

The highest values were obtained from $\mathrm{S}_{4}$ treatments of both variety/rootstock combinations (Table 4). Higher mineral contents in soil were noted because of salinity increase mineral content accumulation in plants (Kalefetoğlu and Ekmekçi, 2005). Salinity stress increased $\mathrm{Na}$ and $\mathrm{Cl}^{-}$accumulation on leaves of fruit trees (Akça and Samsunlu, 2012; Melgar et al., 2008).
Table 5. Effects of salinity on chlorophyll content of 0900/mazzard and 0900/mahaleb trees

\begin{tabular}{|c|c|c|c|c|}
\hline \multirow{2}{*}{$\begin{array}{l}\text { Variety/rootstock } \\
\text { combination }\end{array}$} & \multicolumn{4}{|c|}{ Irrigation water salinity $\left(\mathrm{dSm}^{-1}\right)$} \\
\hline & $\begin{array}{c}0.3 \\
\left(S_{1}\right) \\
\end{array}$ & $\begin{array}{l}2.0 \\
\left(S_{2}\right)\end{array}$ & $\begin{array}{l}4.0 \\
\left(S_{3}\right)\end{array}$ & $\begin{array}{l}6.0 \\
\left(S_{4}\right)\end{array}$ \\
\hline & \multicolumn{4}{|c|}{ Chlorophyll $\mathrm{a}+\mathrm{b}\left(\mathrm{mgg}^{-1}\right)$} \\
\hline 0900/mazzard & $3.72 \mathrm{~A}^{w *} \mathrm{a}^{* *}$ & $3.00 \mathrm{~A}^{n} \mathrm{~b}$ & $2.56 \mathrm{~A}^{2 s} \mathrm{c}$ & $2.14 \mathrm{~A}^{n} \mathrm{~d}$ \\
\hline 0900/mahaleb & $3.50 \mathrm{Aa}^{* *}$ & $2.82 \mathrm{Ab}$ & $2.52 \mathrm{Abc}$ & $2.22 \mathrm{Ac}$ \\
\hline \multicolumn{5}{|c|}{ Decrease (\%) } \\
\hline 0900/mazzard & 0 & 19.4 & 31.2 & 42.5 \\
\hline 0900/mahaleb & 0 & 19.4 & 28.0 & 36.6 \\
\hline
\end{tabular}

Compared to control treatments $\left(S_{1}\right)$, leaf $\mathrm{Na}$ concentrations of saline treatments were $21.5-46.0 \%$ higher in $0900 /$ mazzard and 39.4-67.3\% higher in 0900/mahaleb trees. Na concentration of Colt rootstock (Prunus avium x Prunus pseudocerasus) increased with salt stress $(\mathrm{NaCl})$ (Aricl and Eraslan, 2012). Excluding ability of toxic ions such as $\mathrm{Cl}^{-}$and $\mathrm{Na}$ differs among rootstocks. The excluding ability can be used for selection of commercially acceptable rootstocks (Ayers and Westcot, 1989). Toxic ions of this study showed that $0900 /$ mahaleb rootstock excluded $\mathrm{Na}$ uptake because leaf $\mathrm{Na}$ contents of 0900/mazzard were higher than ones of $0900 /$ mahaleb trees for all saline treatments (Table 4). Irrigation water salinity treatments had significant effects on $\mathrm{Na}$ content of leaves. $\mathrm{S}_{2}, \mathrm{~S}_{3}$ and $\mathrm{S}_{4}$ treatments were in the same group for $0900 /$ mahaleb trees. That means $\mathrm{Na}$ accumulation on leaves did not increase even after 2 $\mathrm{d} S \mathrm{~m}^{-1}$ irrigation water salinity level. According to rootstock effects, $\mathrm{Na}$ content of leaves was different for all treatments, including $S_{1}$ treatment. This difference did not change after salinity treatments.

According to results of $\mathrm{Cl}^{-}$content of leaves, rootstock effects were not significant in $S_{1}$ and $S_{2}$ treatments. $\mathrm{Cl}^{-}$content of leaves of both variety/rootstock combinations were similar. But after $4 \mathrm{dS} \mathrm{m} \mathrm{m}^{-1}$ salinity level, $\mathrm{Cl}^{-}$content of leaves of 0900/mazzard trees was more than 0900/mahaleb trees. According to the effects of salt stress, $\mathrm{Cl}^{-}$content of leaves did not increase after $4 \mathrm{dS} \mathrm{m} \mathrm{m}^{-1}$ irrigation water salinity level for 0900/mazzard trees. $\mathrm{Cl}^{-}$content of leaves for $0900 /$ mahaleb trees increased after $4 \mathrm{dS} \mathrm{m} \mathrm{m}^{-1}$ irrigation water salinity level $\left(\mathrm{S}_{4}\right.$ treatment). In the case of leaf $\mathrm{Cl}^{-}$content, it can be said that 0900/mahaleb rootstock excluded $\mathrm{Cl}^{-}$uptake only under higher saline conditions (for $S_{3}$ and $S_{4}$ ) because $\mathrm{Cl}^{-}$content of $S_{1}$ and $S_{2}$ was lower than those of $S_{3}$ and $S_{4}$ treatments (Table 4 ).

\section{Chlorophyll content}

Chlorophyll $a$ and chlorophyll $b$ contents are presented in Fig. 6. Chlorophyll content $(a+b)$ was affected by salinity levels in both variety/rootstock combinations (Table 5 ). There were no significant differences in chlorophyll contents of rootstocks. Reductions in chlorophyll content were similar for both rootstocks. It can be said that salt stress affected chlorophyll content of both rootstocks similarly. With regard to salt stress effects, there were four statistical groups for mazzard and three groups for mahaleb rootstocks. Salt stress had clear effects on chlorophyll content of 0900/mazzard. Salt stress causes decreasing photosynthesis activity and affects the chlorophyll 
220

content of leaves. These parameters are associated with plant species, stress intensity and duration (Dubey, 1994; Mishra et al., 1997). Chlorophyll content of sweet cherry rootstocks decreased while salt stress increased (Ertürk et al., 2007; Sotiropoulos et al., 2006).

\section{Conclusions}

In this study it was determined that '0900 Ziraat' sweet cherry variety grafted on mazzard (Prunus avium L.) and mahaleb (Prunus mahaleb L.) rootstocks were affected by increasing salinity levels in irrigation water. By using saline irrigation water, soil salinity increased, but water consumption decreased. Although similar root development results were observed in both variety/rootstock combinations, different plant fresh weight results were determined. Increasing salt stress caused more plant deaths in '0900 Ziraat' grafted on mazzard rootstocks. $\mathrm{Na}$ and $\mathrm{Cl}^{-}$toxic ion accumulation in leafs was appreciably lower for 0900/mahaleb trees. The result showed that 0900/mazzard trees were negatively affected by salinity, more than $0900 /$ mahaleb trees. It was recommended that 0900/mahaleb trees should be used in cherry culture under saline conditions.

\section{References}

Akça Y, Samsunlu E (2012). The effect of salt stress on growth, chlorophyll content, proline and nutrient accumulation and $\mathrm{K} / \mathrm{Na}$ ratio in walnut. Pakistan Journal of Botany 44(5):1513-1520.

Arıcı, ŞE, Eraslan F (2012). Effect of salt-stress on shoot growing, chlorophyll and minerals content sweet cherry rootstock Colt (Prunus avium $\mathrm{x}$ Prunus pseudocerasus) cultured in vitro. Süleyman Demirel University Journal of Agricultural Faculty 7(2):41-48 (in Turkish).

Ashraf M (2004). Some important physiological selection criteria for salt tolerance in plants. Flora 199:361-376.

Ashraf M, Foolad MR (2007). Improving plant abiotic-stress resistance by exogenous application of osmoprotectants glycine betaine and proline. Environment and Experimental Botany 59:206-216.

Ayers RS, Westcot DW (1989). Water quality for agriculture. FAO Irrigation and Drainage Paper No. 29, FAO, Rome.

Blumwald E, Aharon GS, Apse MP (2000). Sodium transport in plant cells. Biochimica et Biophysica Acta 1465:140-151.

Demirtaş İ, Sarısu HC (2011). Sweet cherry growing. Bulletins of Fruit Research Station, Eğirdir, Isparta-Turkey, Publishment number 11:12 p. (in Turkish).

Dubey RS (1994). Protein synthesis by plants under stressful conditions. In: Pessarakli M (Ed), Handbook of Plant and Crop Stress, Marcel Dekker Inc., New York pp 277-299.

Düzdemir O, Ünlükara A, Kurunç A (2009). Response of cowpea (Vigna unguiculata) to salinity and irrigation regimes. New Zealand Journal of Crop and Horticultural Science 37:271-280.

Downton, WJS, Loveys BR, Grant WJR (1990). Salinity effects on the stomatal behaviour of grapevine. New Phytologist 116(3):499-503 499-503.
Eroğul D (2012). The Use of Rootstocks in Cherry Growing. Adnan Menderes University Journal of Agricultural Faculty 9(2):19-24 (in Turkish).

Ertürk U, Sivritepe N, Yerlikaya C, Bor M, Ozdemir F, Turkan I (2007). Responses of the cherry rootstock to salinity in vitro. Biologia Plantarum 51(3):597-600.

FAO (2013). FAO. http://faostat3.fao.ong/home/index.html\#DOWNLOAD (Accessdate 30.11.2014).

Germana C, Cutore L, Sardo V (2000). Assessing tolerance to irrigation water salinity in five woody plants. Special Session on Nonconventional Water Resources Practices and Management and Annual Meeting, UWRM Sub-Network Partners, IAV Hassan II, Rabat, Morocco, 151-159.

Hasegawa PM, RA Bressan, Handa AK (1986). Cellular mechanisms of salinity tolerance. HortScience 21:1317-1324.

Kalefetoğlu T, Ekmekçi Y (2005). The effect of drought on plants and tolerance mechanisms. Gazi University Journal of Science 18(4):723-740 (in Turkish).

Karakas B, Lo Bianco R, Rieger M (2000). Association of marginal leaf scorch with sodium accumulation in salt-stressed peach. HortScience 35(1):83-84.

Kotuby-Amacher J, Koening R, Kitchen B (2000). Salinity and plant tolerance. Utah State University Extension, Logan, AG-SO-03. 17 Febr 2010. http://extension.usu.edu/htm/publications.

Lauchli A, Epstein E (1990). Plant response saline and sodic conditions, Agricultural Salinity Assesment and Management. Tanji K(Ed), ASCE Manuals and Reports on Engineering Practise No. 71:113137.

Lutfor Rahman SM, Nawata E, Sakuratani T (1999). Effect of water stress on growth, yield and eco-physiological responses of four tomato (Lycopersicon esculentum Mill.) cultivars. J Japan Soc Hort Sci 68(3):499-504.

Martinez-Barraso MC, Alvarez CE (1997). Toxicity symptoms and tolerance of strawberry to salinity in the irrigation water. Scientia Horticulturae 71:177-188.

Melgar JC, Syvertsen JP, Martínez V, García-Sánchez F (2008). Leaf gas exchange, water relations, nutrient content and growth in citrus and olive seedlings under salinity. Biologia Plantarum 52(2):385-390.

Mishra SK, Subralimanyam D, Singhal GS (1997). Interactionship between salt and light stress on the primary process of photosynthesis. Journal of Plant Physiology 38:92-96.

Munns R, Tester M (2008). Mechanisms of salinity tolerance. Annual Review of Plant Biology 59:651-681.

Murkute AA, Sharma S, Singh SK (2005). Citrus in terms of soil and water salinity: A review. Journal of Scientific and Industrial Research 64:393-402.

Okubo M, Sakuratani T (2000). Effects of sodium chloride on survival and stem elongation of two Asian pear rootstock seedlings. Scientia Horticulturae 85:85-90.

Öztürk FP, Karamürsel D, Bayav A,Öztürk G (2005). Sweet cherry production, marketing and marketing potential. GAP (South East Agriculture Project) IV. Agricultural Congress, 21-23 September, Şanliurfa 2:1430-1435 (in Turkish). 
Parker FP, Suarez DL (1990). Irrigation water quality assessments, agricultural salinity assessment and management. Tanji K (Ed), ASCE Manuals and Reports on Engineering Practice No:71, NY, USA, 221-236.

Perry R (1987). Cherry rootstocks, pp 145-183. In: Rootstocks for fruit crops. Rom RC, Carlson RF (Eds). New York: John Wiley.

Pitman MG, Läuchli A (2002). Global impact of salinity and agricultural ecosystems. In: Läuchli A, Lüttge U (Eds). Salinity: environment-plants-molecules. Dordrecht, the Netherlands: Kluwer Academic Publishers, 522p, 3-20 pp.

Richards L A (1954). Diagnosis and improvement of saline and alkali soils. Agricultural Handbook No. 60, United States Department of Agriculture. Washington, DC, USA.

Reddy MP, Iyengar, ERR (1999). Crop responses to salt stress: Seawater Application and Prospects. Handbook of Plant Crop Stress, New York, USA, 1198 p.

Semiz GD, Ünlükara A, Yurtseven E, Suarez DL, Telci İ(2012). Salinity impact on yield, water use, mineral and essential oil content of fennel (Foeniculum vulgare Mill.) Journal of Agricultural Sciences 18:177186.

Shannon MC, Grieve CM (1999). Tolerance of vegetable crops to salinity. Scientia Horticulturae 78:5-38.

Smets SMP, Kuper M, Van Dam JC, Feddes RA (1997). Salinization and crop transpiration of irrigated fields in Pakistan's Punjab. Agricultural Water Management 35(1-2):43-60.
Sotiropoulos TE, Dimassi KN, Tsirakoglou V, Therios IN (2006). Responses of two prunus rootstocks to $\mathrm{KCl}$ induced salinity in vitro. Biologia Plantarum 50:477-480.

Tanji KK (1990). Agricultural salinity assessment and management. Manuals and Reports on Engineering Practice Number 71. American Society of Civil Engineers, New York USA, p 619.

Tattini M, Gucci R, Coradeschi MA, Ponzio C, Everard JD (1995). Growth, gas exchange and ion content in Olea europaea plants during salinity stress and subsequent relief. Physiologia Plantarum 95:203-210.

Tuteja N (2007). Mechanisms of high salinity tolerance in plants. Methods in Enzymology 428:419-438.

Ünlükara A, Kurunç A, Kesmez GD, Yurtseven E, Suarez DL (2010). Effects of salinity on eggplant (Solanum melongena L.) growth and evapotranspiration. Journal of Irrigation and Drainage 59:203-214.

Yang LS, Yano T, Aydın M, Kitamura Y, Takeuchi S (2002). Short term effects of saline irrigation on evapotranspiraton from lysimetergrown citrus trees. Agricultural Water Management 56:131-141.

Yurtseven E, Kesmez GD, Ünlükara A (2005). The effects of water salinity and potassium levels on yield, fruit quality and water consumption of a native central anatolian tomato species (Lycopersicon esculentum). Agricultural Water Management 78(12):128-135.

Withan FH, Blaydes DF, Devlin RM (1971). Experiments in plant physiology. Von Nostrand Reinhold Co., New York pp 55-58. 